\title{
COCAINE CARDIOMYOPATHY — A CASE REPORT
}

\author{
Georgiev Antonio, ${ }^{1}$ Zhivadinovik Julija ${ }^{2}$ \\ ${ }^{1}$ University Clinic for Cardiology, Medical Faculty, Skopje, University "Ss. Cyril and Metodius", R. Macedonia \\ ${ }^{2}$ Institute of Anatomy, Medical Faculty, Skopje, University "Ss. Cyril and Metodius", R. Macedonia
}

Primljen/Received 05. 08. 2014. god.

Abstract: Cocaine is the second most common illicit drug used and the most frequent cause of drug related deaths. The use of cocaine is associated with both, acute and chronic complications, that may involve any system, but the most common system affected is cardiovascular one. Cocaine cardiomyopathy may result from the use of cocaine.

This article presents a first case in Republic of Macedonia of 24-year-old male with reversible cocaine-related cardiomyopathy. Clinical presentation, laboratory, X-ray, ultrasound findings and treatment are reviewed.

Key words: cocaine, cocaine cardiomyopathy, diagnosis, treatment.

\section{INTRODUCTION}

Cocaine is the second most common illicit drug used and the most frequent cause of drug related deaths. In a retrospective of European study of 479 ACS patients younger than 50 years admitted to a critical care unit from 2001 to 2008 , a total of 24 patients (5\%) had adnitted to recent cocaine abuse or tested positive on urine drug screening (1). In 2005, 2.4 million persons were actively using cocaine. The younger age groups of $18-25$ are the most common users and it is estimated that $11 \%$ of the population has used it at some point (2). The 2008 National Survey on Drug Use Health reported that approximately 36.8 million Americans aged 12 years and older (14.7\% of Americans in that age group) had tried cocaine at least once (3). The trade with this illicit drug in Republic of Macedonia is prosecuted by law. Yet there are people who use this drug and have complications from it.

Cocaine acts as a powerful sympathomimetic agent. It blocks the presynaptic reuptake of norepinephrine and dopamine producing high level of these neurotransmitters at the postsynaptic receptors. It also may increase the release of catecholamines from central and

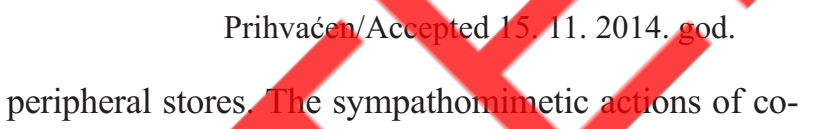
caine, at cellular level, are mediated by stimulation of the $\alpha$ and $\beta$ adrenergic receptors. Cocaine also interacts with the muscarinic receptors, and inhibits the reuptake of dopamine and seretonin by nerve endings (1).

Cocaine intoxication usually presents with symptoms of adrenergic excess. Hypertension, occasionally in the range of hypertensive crisis, may be present. Cerebral vascular aecidents of either thrombotic or hemorhagic origin are not uncommon. Acute delirium and mania may be present, particularly if other drugs were sed concurrently (2).

The use of cocaine is associated with both acute and chronic complications that may involve any system, but the most common system affected is cardiovascular one (2-6). Cocain related complications include: cardiac (myocardial ischaemia, coronary artery spasm, myocardial infarction (MI), atherosclerosis, myocarditis, cardiomyopathy, arrhythmia, hypertension, and endocarditis); vascular (aortic dissection and rupture, vasculitis); gastrointestinal (mesenteric ischaemia or infarction, perforation); pulmonary (pulmonary oedema, pulmonary infarction, and haemoptysis); genitourinary and obstetric (renal and testicular infarction, abruptio placentae, spontaneous abortion, prematurity, and growth retardation); neurological (seizures, migraine, cerebral infarction, and intracranial hemorrhage); musculoskeletal and dermatological (rhabdomyolysis, skin ischemia, superficial and deep venous thrombosis, and thrombophlebitis (2-6).

\section{CASE REPORT}

We present a case of a twenty four years old male, with a history of inhaling vaporized cocaine, and marihuana for two years. The main complaints of patient were fatigue, labored respiration, especially at night, dyspnea, anxiety, increased heart rate and lost of appetite during last $2-3$ months. The patient was conscious, 
anxious, oriented to time, space and persons. Heart sounds were clear with systolic murmur. The ECG showed sinus tachycardia (HR > 100/min) (Figure 1) and about $0,5 \mathrm{~mm}$ upsloping ST segment depression in lateral leads. Blood pressure was elevated (150/105 $\mathrm{mmHg})$. Laboratory analysis showed elevation of blood Urea $(10.6 \mathrm{mmol} / \mathrm{L})$, Creatinine $(154 \mathrm{mmol} / \mathrm{L})$, $\mathrm{Na}(149 \mathrm{mEq} / \mathrm{L}), \mathrm{K}(4.2 \mathrm{mEq} / \mathrm{L})$ and iron-deficiency anemia with $\mathrm{Fe}(7.1 \mathrm{mcg} / \mathrm{dl})$. X-ray findings obtained enlarged heart silhouette (Figure 2). Echocardiographic evaluation showed left chamber dilatation with reduced global systolic function and ejection fraction (EF) $38 \%$, designated mitral cusps with posterior cusp prolapsed, thin regurgitated flow and intraatrial septum tissue changes.

Preceding therapy Carvedilol and Acetylsalicylic acid was changed to heart failure - guideline-based heart failure therapy: Carvedilol, nonselective alfa/beta - adrenergic blocker ( 2 × 6,25 mg per day), Perindopril, ACE inhibitor (4 mg per day), Spironolactone, mineral corticoid receptor antagonist, MRA (25 mg per day), Thiazide diuretic ( $25 \mathrm{mg}$ per day) and Acetylsalicylic acid (100 mg per day). Therapy for correction of anemic syndrome was recommended. Cocaine cessation was obligated.

Two months later, after cocaine cessation and treatment in specialized hospital, the patient didn't fill the symptoms from the first examination, but he was at bad physical condition. Laboratory findings were normal zed: Urea $7.6 \mathrm{mmol} / \mathrm{L}$; Creatinin $108 \mathrm{mmol} / \mathrm{L}, \mathrm{Na} 13$ $\mathrm{mEq} / \mathrm{L} ; \mathrm{K} 4.2 \mathrm{mEq} / \mathrm{L}$ and $\mathrm{Fe} 16.2 \mathrm{mgg} / \mathrm{dl}$. EKG showed sinus rhythm with HR $65 / \mathrm{min}$. Blood pressure was $120 / 80 \mathrm{~mm} \mathrm{Hg}$. Dimensions of left ventricle were in referent values. Left ventricle function was slightly reduced with EF $49 \%$, mitral cusps were designated with posterior cusp prolapsed and intratrial septum tissue changes. The patient continued with the same therapy.

The patient abstained from cocaine use and five months later he didn't fill any of the symptoms from the first examination, and he was in good physical condition. Laboratory findings were in the ranges of referent values. Left and right ventricles function and dinensions were preserved. Left ventricle EF was $62 \%$. The patient continued with medications: Nebivolol,

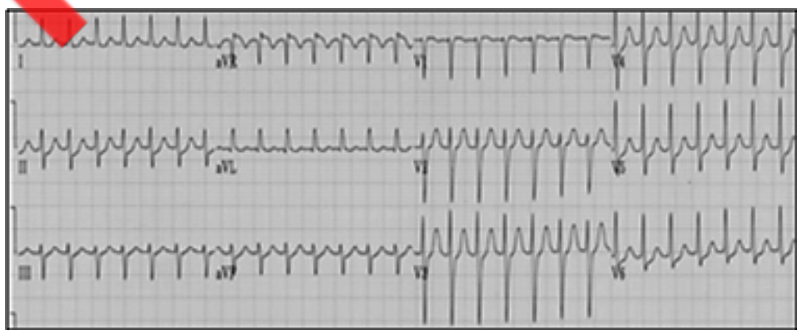

Figure 1. ECG findings

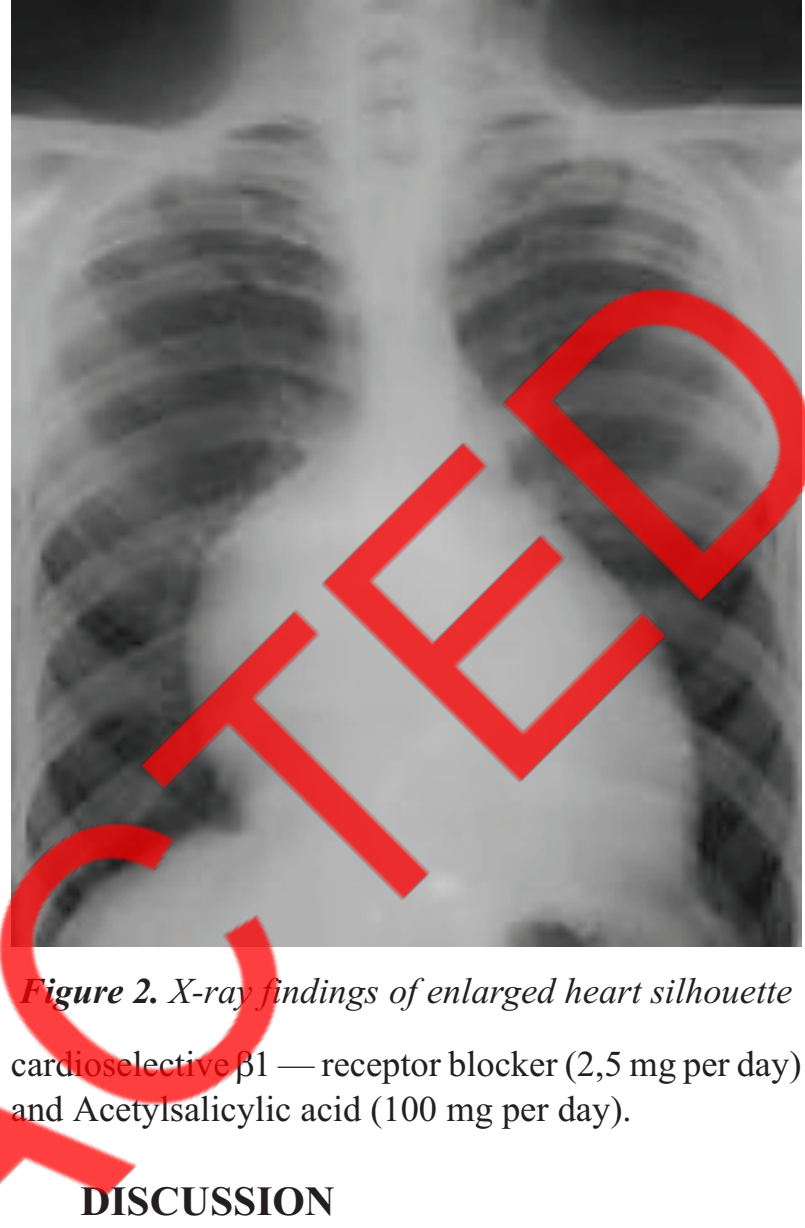

Cocaine users may have various symptoms referable to the cardiac system. Symptoms can include chest pain with or without myocardial ischemia or aortic dissection, hypertension with or without hypertensive crisis, cerebral ischemia, and hemorrhage. Patients also may present with acute myocardial decompensation with or without pulmonary edema and shock. In this case, shortness of breath and hypoperfusion dominate the clinical picture $(1,6,7,8)$.

Morbidity and mortality information associated with cocaine-related cardiomyopathy is commonly based on case reports $(9,10)$. Chokshi et al. were among the first authors to describe a reversible cocaine-related cardiomyopathy. The patient in their report, a 35-year-old woman, underwent endomyocardial biopsy that failed to reveal any necrosis, fibrosis, or inflammatory infiltrate (9).

While most cases of cocaine-related cardiomyopathy have proved to be reversible, others have resulted in permanent cardiac dysfunction or death. The symptoms of cocaine-related cardiomyopathy are the same as symptoms for other forms of congestive heart failure. The onset may be very sudden and of short duration. A cocaine-related etiology for cardiomyopathy should be suspected in any patient with a history of cocaine use, particularly binge use, and heart failure, wit- 
hout another established etiology for the heart failure, such as coronary artery disease. If the clinical suspicion is high, the diagnosis of cocaine use should be investigated with a urine screen for cocaine and its metabolites. The typical patient with cocaine cardiomyopathy is a young male smoker who presents with signs of adrenergic excess $(5,10)$. With acute binge use of cocaine, the patient may present with acute congestive heart failure and pulmonary edema. Hypotension, rater than hypertension, may predominate, making the diagnosis and treatment more difficult. Cocaine-related cardiomyopathy presents more acutely than other types of congestive heart failure, and fewer findings of chronic congestive heart failure are present. Otherwise, the physical findings are similar. Diaphoresis, pallor, and acute dyspnea are present. Cardiogenic shock or evidence of cardiac ischemia also may be present.

The laboratory investigation of cardiomyopathy of any etiology generally shows abnormalities of electrolytes, usually anemia and compromised renal function, with elevation of blood urea nitrogen (BUN) and creatinine.

Cocaine usually is evident on a urine toxicology screen, because these cases almost always present immediately after use of the drug. Because individuals who use cocaine are predisposed to the development of endocarditis, consider blood cultures if the setting is a all appropriate.

In cases of cardiomyopathy, the chest radiograph usually shows evidence of cardiomegaly and eongestive heart failure. Evidence of septic embolimay be present if endocarditis is present. The radiograph may be normal in many case

Echocardiographic evaluation shows chamber dilation and global dysfunction or regional wall motion abnormalities if myocardial infarction is present. Echocardiographic studies have shown that individuals who abuse cocaine have an increased left ventricular mass-index with a higher tendency toward increased osterior wall thicknes

Cardiac catheterization usually shows normal coronary arteries or only minimal disease, even in the prece of myocardial infarction.

In cases of cardiomyopathy, the ECG is not specific but may show evidence of left ventricular hypertrophy and nonspecific ST-T wave changes. Arrhythmias also may be detected, and continuous monitoring may be advisable.

In autopsies of 40 patients, 31 of whom died cocaine-related deaths and 9 of whom were homicide victims with detectable blood cocaine levels, Virmani et al. found that $20 \%$ of the patients showed evidence of myocarditis on toxic screening tests (11). Tazelaar, in an autopsy study, reported contraction-based myocardial necrosis similar to that observed in pheochromocytoma (12).

In a case report by Robledo-Carmona, histologic findings of the left ventricular myocardium included sparse mononuclear infiltrates associated with degenerative changes, myocyte necrosis, and severe interstitial fibrosis (13).

\section{Management}

Associations of cardiologists don't have recommendations for concrete medicamentous treatment of cocaine cardiomyopathy (1). Management of these patients is similar to that of patients with other forms of dilated cardiomyopathy, although beta-blockers should be included inpatients with cocaine-associated heart failure and benzodiazepines should be given in this setting to blunt adrenergic excess. If shock is present, inotropic agents and vasopressors are indicated. If evidence of ongoing ischemia is present, aggressive use of agents directed at relieving vasospasm (nitrates and calcium channel blocking drugs) are indicated. Endotracheal intubation may be necessary. If arrhythmias are present and are felt to be compromising the clinical tuation, they should be treated aggressively. The use beta-blocking drugs as single agents is contraindicated. For the purpose of these patients need to know and be used in medical practice cardiac magnetic resonance as a method that is quite useful for predicts reversibility of cocaine-induced ventricular dysfunction (1, $14,15,16)$.

John McMurray et al. ESC Guidelines for the diagnosis and treatment of acute and chronic heart failure 2012 (17) recommend the following therapy:

An ACE inhibitor in addition to the beta-blocker is used for all patients with an $\mathrm{EF} \leq 40 \%$ to reduce the risk of heart failure hospitalization and the risk of premature death. A beta-blocker in addition to an ACE inhibitor is used for all patient with an $\mathrm{EF} \leq 40 \%$ to reduce the risk of heart failure, hospitalization and the risk of premature death. An MRA is recommended for all patients with persisting symptoms and $\mathrm{EF}<35 \%$, despite treatment with ACE inhibitor and a beta-blocker to reduce the risk of heart failure hospitalization and the risk of premature death. It is good to mention that analysis of B-type natriuretic peptide (BNP) level can help monitor the presence of congestive heart failure. Also BNP is very helpful to monitor response to treatment.

In most of reported cases of cocaine-related cardiomyopathy, patients have shown significant improvement following the cessation of cocaine use. In some cases, patients have returned to normal cardiac func- 
tion, but recurrence is reported if the patient relapses into cocaine use (5).

Efforts to assist the patient with their drug addiction should be a part of every treatment plan. Hospitalization for detoxification may be necessary, particularly if other drugs also are being abused. Outpatient treatment of drug dependence is strongly advised. Abstinence from cocaine use and long time follow up is mandatory.

\section{CONCLUSION}

This is the first publication of cocaine-related cardiomyopathy in our country. Physicians usually don't consider the possibility of cocaine use of their patients. Many cocaine users have little or no idea of the risks associated with its use. So, patients, health care work- ers and the public should be educated about the dangers and the considerable risks of cocaine use.

\section{Abbreviations}

ACE - Angiotensin converting enzyme

BNP - Natriuretic peptide

BUN - Blood urea nitrogen

ECG - Electrocardiography

$\mathbf{E F}$ - Ejection fraction

ESC - European Society of Cardiology

HR - Heart rate

MI - Myocardial infarction

MRA - Minetal corticoid receptor antagonist

ST - ECG between the end of the S wave (the J

point) and the beginning of the

\section{Sažetak}

\section{KOKAINSKA KARDIOMIOPATIJA — PRIKAZ SLUČAJA}

\section{Georgiev Antonio, ${ }^{1}$ Zhivadinovik Julija ${ }^{2}$}

${ }^{1}$ Univerzitetska Klinika za kardiologiju, Univerzitet „Sv Ćirilo i Metodije“, Medicinski fakultet, Skoplje, R. Makedonija

${ }^{2}$ Institut za anatomiju, Univerzitet „Sv. Cirilo iMetodije“, Medicinski fakultet, Skoplje, R. Makedonija

Kokain je druga najčešća nezakonita droga koja se koristi i najčešći uzrok smrti zbog droge. Upotreba kokaina daje akutne i hronične komplikacije, koje mogu uključivati bilo koji sistem organa, najčeš kardiovaskularni sistem.Kardiomiopatija može biti izazvana konzumiranjem kokaina. Ovaj članak predstavlja slučaj dvadesetčetvorogodišnjeg muškarca s

\section{References}

Finkel JB, Mathefka GD. Rethinking cocaine-associated chest pain and acute coronary syndromes. Mayo Clin Proc. 2011; 86(12): 1198-207.

2. Egred M, Davis GK. Cocaine and the heart. Postgrad Med J. 2005; 81(959): 568-71.

SAMHSA Substance abuse and mental health service administration. Sharp decline also continues for methamphetamine use. US Department of Health and Human Services (DHS); Office of Applied Studies Results from the 2008 National Survey on Drug Use and Health: National Findings. http://oas.samhsa.gov/nsduh/2k8nsduh/2k8Results.cfm. 2009.

4. Phillips K, Luk A, Soor GS, Abraham JR, Leong S, Butany J. Cocaine cardiotoxicity: a review of the pathophysiology, pathology, and treatment options. Am J Cardiovasc Drugs. 2009; 9(3): 177-96.

5. Schwartz BG, Rezkalla S, Kloner RA. Cardiovascular effects of cocaine. Circulation. 2010; 122(24): 2558-69.

6. Awtry EH, Philippides GJ. Alcoholic and cocaine-associated cardiomyopathies. Prog Cardiovasc Dis. 2010; 52(4): 289-99. reverzibilnom kokainskom kardiomiopatijom, što predstavlja prvi takav u Republici Makedoniji. Nalazi kliničkog pregleda, laboratorijskih analiza, rendgengrafije srca i pluća, ultrazvuka srca i tretman su prikazani.

Ključne reči: kokain, kokainska kardiomiopatija, dijagnoza, lečenje.

7. Freeman K, Feldman JA. Cocaine, myocardial infarction, and $\beta$-blockers: time to rethink the equation? Ann Emerg Med. 2008; 51(2): 130-4.

8. Bhargava S, Arora RR. Cocaine and cardiovascular complications. Am J Ther. 2011; 18(4): e95-e100.

9. Velasquez EM, Anand RC, Newman WP 3rd, Richard SS, Glancy DL. Cardiovascular complications associated with cocaine use. J La State Med Soc. 2004; 156(6): 302-10.

10. Chokshi SK, Moore R, Pandian NG, Isner JM. Reversible cardiomyopathy associated with cocaine intoxication. Ann Intern Med. 1989; 111(12): 1039-40.

11. Virmani R, Robinowitz M, Smialek JE, Smyth DF. Cardiovascular effects of cocaine: an autopsy study of 40 patients. Am Heart J. 1989; 115(5): 1068-76.

12. Tazelaar HD, Karch SB, Stephens BG, Billingham ME. Cocaine and the heart. Hum Pathol. 1987; 18(2): 195-9.

13. Robledo-Carmona J, Ortega-Jimenez MV, Garcia-Pinilla JM, Cabra B, de Teresa E. Severe Cardiomyopathy Associated to Cocaine Abuse. Int J Cardiol. 2006; 112(1): 130-1.

14. Rangel C, Shu RG, Lazar LD, Vittinghoff E, Hsue PY, Marcus GM. Beta-blockers for chest pain associated with recent cocaine use. Arch Intern Med 2010; 170(10): 874-9. 
15. Littmann L, Narveson SY, Fesel MN, Marconi SL. Beta blocker treatment of heart failure patients with ongoing cocaine use. Int J Cardiol. 2013; 168(3): 2919-20.

16. Smedema JP. Cardiac magnetic resonance predicts reversibility of cocaine-induced ventricular dysfunction. Cardiovasc J Afr. 2009; 20(3): 198-9.

\section{Correspondence to /Autor za korespondenciju}

Georgiev Antonio

University Clinic for Cardiology

Vodnjanska bb

1000 Skopje, Republic of Macedonia e-mail: antoniogeorgiev@yahoo.com tel: 0038970305114
17. McMurray JJ, Adamopoulos S, Anker SD, Auricchio A, Bohm M, Dickstein K, et al. ESC Guidelines for the diagnosis and treatment of acute and chronic heart failure 2012: The Task Force for the Diagnosis and Treatment of Acute and Chronic Heart Failure 2012 of the European Society of Cardiology. Developed in collaboration with the Heart Failure Association (HFA) of the ESC. Eur Heart J. 2012; 33(14): 1787-847.

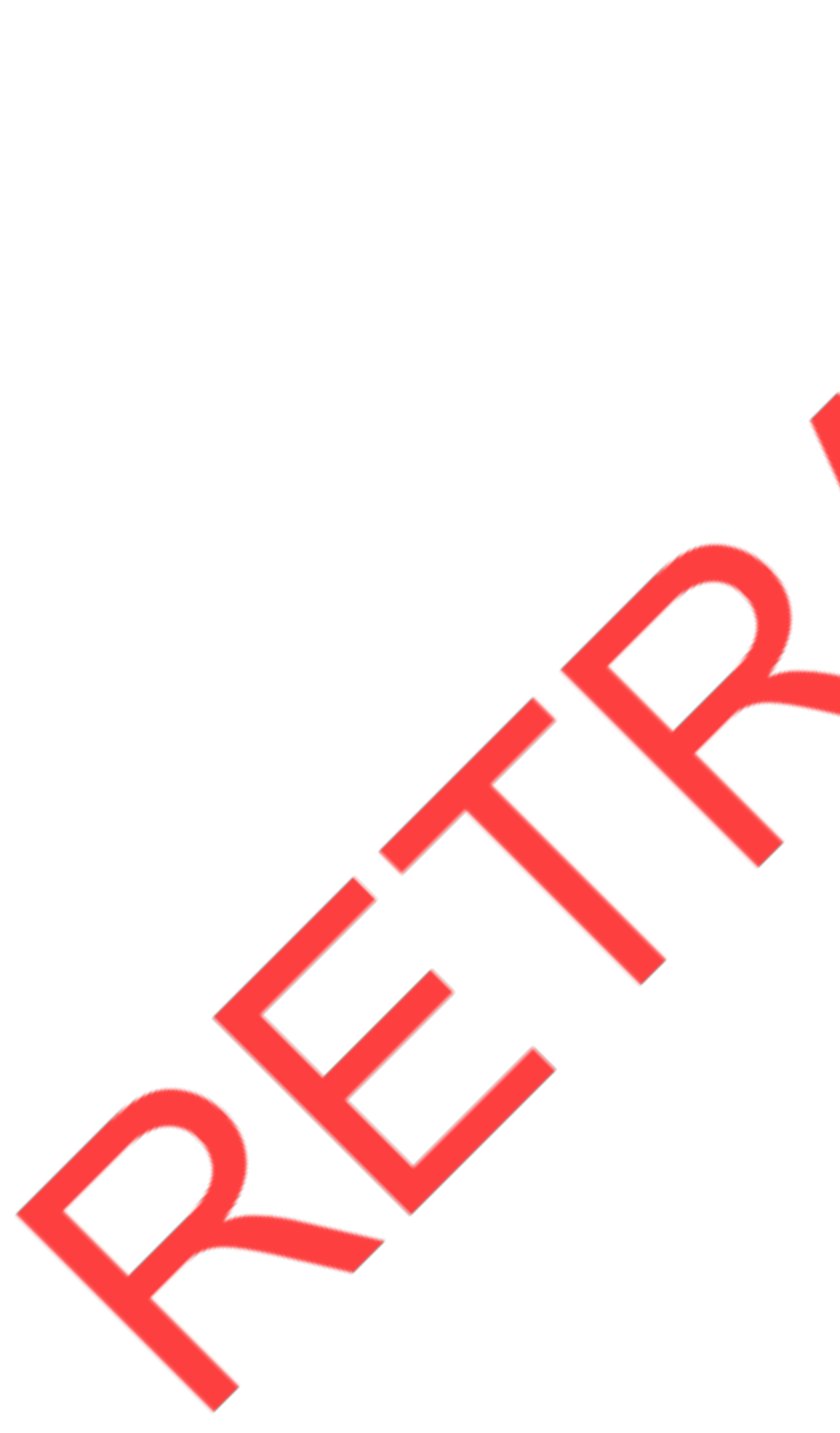

